Shipbuilders on Friday, October 23, Prof. C. J. Hawkes took as his main theme "The Training of the Engineer" and, as a background, his work and experience in the revision of the engineering degree courses at the University of Durham lent an unusual interest and value to his remarks. Engineering is not a science but an art depending on science and, between the two, there are still many gaps, which the engineer has to bridge. His decisions have to be in a form capable of being translated into practice, and he has to be trained to make use of established scientific principles in conjunction with a knowledge of the needs of the world, of the natural forces to be contended with, of the properties of the materials to be used, of the capacities and limitations of those through whom the work has to be done and of the plant, tools, and machinery on which the processes depend. Prof. Hawkes indicated how the curricula at Durham have been revised to comply with these comprehensive demands. The more human aspects are provided for by weekly reports and discussions in college, and by the personal contact during the workshop training with men of all classes, perhaps the most broadening influence that could be found. By the limitation of available time, the graduate course is mainly confined to the study of scientific principles and their applications. Such subjects as economies, works organization and administration are considered preferably as post-graduate studies. Prof. Hawkes also took occasion to report the progress of research work at Armstrong College. which has been greatly fostered by the members of the Institution he was addressing.

\section{Observatory for St. Albans High School for Girls}

ON Oetober 23, Sir Frank Dyson inaugurated at St. Albans High School for Girls the observatory recently bequeathed to the school by the late Dr. William Alfred Parr. Dr. Parr, a well-known amateur astronomer and past-president of the British Astronomical Association, resided in St. Albans during the last few years of his life, and had erected in his garden a small but well-equipped observatory, containing a four-inch clock-driven equatorial by Cooke, with a photo-visual object-glass, Evershed solar spectroseope and other accessories. The entire observatory, which is of wood, surmounted by a 10-foot revolving dome, was, with its small annexe, removed from Dr. Parr's garden during the summer, and re-erected in the school grounds near the new gymnasium, under the supervision of Dr. W. H. Steavenson. Following an address by Sir Frank to the staff and pupils, assembled in the latter building, the observatory was formally opened and dedicated with picturesque ceremony, the Dean of St. Albans, the senior science mistress and the head girl taking part.

\section{Food and the Family Budget}

THE Engineers' Study Group on Economies, which was formed towards the end of 1933 to investigate the economic and social problems presented by the co-existence of poverty and actual or potential plenty, has now published its investigations on family budgets in a pamphlet entitled "Food and the Family Budget" (Engineers' Study Group, Hazlitt House, Southampton Buildings, W.C.2. 1s. 6d.). This investigation has been confined to conditions as they exist in Great Britain to-day. The problem is treated quantitatively, and an attempt is made to deduce some general minimum standard of living which would be both desirable and practicable. The method used was that of analysing and comparing published data on family budgets, at the same time taking into consideration modern trends in consumption and requirements indicated by scientific research. The total budget required to provide the minimum standard desirable was found for a "statistical average family" of $3 \cdot 72$ persons to be about $£ 6$ per week (equivalent to about $63 s$. per week for each wage earner) and of this sum about 37s. a week would be required for expenditure on food. The suggested food budget is shown to be compatible with $(a)$ the dietetic requirements laid down by the British Medical Association Committee on Nutrition; (b) actual national consumption; and (c) the increased consumption of home-grown foodstuffs that would raise the dietetic standard to a level adumbrated by Sir John Orr. There is little doubt, it is stated, that a large part of the population is suffering from lack of nutritious foodstuffs, particularly fresh dairy produce, fruit and vegetables.

\section{Noise on the Road}

The Departmental Committee which was set up in 1934 by the Minister of Transport, under the chairmanship first of Sir Henry Fowler and afterwards of Dr. G. W. C. Kaye, to study the question of motor-vehicle noises, has issued its second interim report (London: H.M. Stationery Office. 18. net). The report elaborates and extends the first report of the Committee, which dealt with new vehicles including motor-cars, sports-cars, motor-cycles and goods-and passenger-carrying vehicles. It appears from the report that a consensus of opinion considered that a loudness of ninety British standard phons represents in general a transition point between tolerably noisy vehicles and unduly noisy ones. Two types of tests are therefore proposed by the Committee : (a) normal-running tests in which a vehicle running under full throttle at 30 m.p.h. must not generate an overall noise exceeding 90 phons at 18 feet lateral distance; (b) racing-engine tests in which a stationary vehicle the engine of which is racing at maximum-power speed must not generate an overall noise exceeding 90 phons at 25 feet behind the open end of the exhaust pipe. A temporary tolerance limit is suggested for motor-cycles and commercial vehicles. In the meantime, the Minister has received an assurance from the manufacturers of motor-cycles and sports-cars, which are among the chief offenders on the road, that no new vehicle shall in future leave their works the noise of which can be regarded as offensive. The Ministry of Transport is proposing to set up six noise-testing stations to assist the industry in this laudable object. Meanwhile, work is 
proceeding on the production of a simplified objective noise meter so as to facilitate its production in greater numbers. Detailed results of the tests, which were carried out by the National Physical Laboratory, are given in the report.

\section{Recent Acquisitions at the Natural History Museum}

Tre Museum has received as a permanent loan from His Majesty the King a fine series of elephant tusks. The series comprises the record pair of Indian tusks, three pairs and a single large tusk of the African species, and an ornamented tusk of the Malayan elephant. The Indian tusks, which are figured in Rowland Ward's "Records of Big Game", are of exceptional size for Indian wvory, measuring $8 \mathrm{ft} .9 \mathrm{in}$. and $8 \mathrm{ft} .6 \frac{1}{2} \mathrm{in}$. in length and weighing $161 \mathrm{lb}$. and 160 b. respectively. Good Indian tusks rarely exceed 6-7 ft. in length or weigh more than $80-100 \mathrm{lb}$. The Trustees of the American Museum of Natural Historv, New York, have handed over to the National collection the type specimens of fifteen races of British and Irish birds, described by the late Dr. E. Hartert and Mr. H. F. Witherby. These types formed part of the famous Rothschild collection which was purchased by the American Museum in 1932. Through the generosity of Mr. E. C. Stuart Baker, the Museum has received the largest collection of birds' eggs ever presented to the British Museum. This great collection consists of approximately 50,000 eggs belonging to some 1,960 different species of birds found in the Indian Empire. Very many of these eggs were not previously represented in the national collection and in a considerable number of cases Baker's specimens are the only ones known. A collection of more than 6,000 invertebrates, chiefly Brachiopoda and Trilobita, including 40 new species, as well as type and figured specimens, collected by Mr. B. B. Bancroft with great exactness as to horizon and locality, from the Ordovician of the Welsh Borderland and the Lake District, has been purchased for the Department of Geology. The Mineral Department has received from the Director of the Geological Survey of Nigeria as a donation a piece, besides several fragments, of the meteoric stone which fell near Udei station, Benue river, Nigeria, in 1927. The meteorite is of unusual interest because it belongs to the rare pallasite group of stony-irons containing olivine.

The Department of Botany has received from Mr. C. J. Brooks his fern herbarium, containing about 2,650 specimens. Mr. Brooks was employed as a chemist in the gold-mining industry in Sarawak and later in Sumatra, where he collected insects and ferns. He discovered many new species in the mountains of Borneo and Sumatra, including Gunong Dempo. $\mathrm{He}$ also visited Celebes and Amboina. In the latter island he made a very complete collection and ascended the voleano Salahoetoe. Mr. Brooks's plants were mostly worked out by Capt. C. R. W. K. van Alderwerelt van Rosenburgh at Buitenzorg, and many are types or paratypes not otherwise represented in Europe. He was also in touch with Prof.
E. B. Copeland and the late Prince Roland Bonaparte, and obtained some specimens by exchange. Especially notable are a set of Schlechter's New Guinea ferns and some from Papua collected by the Rev. Copland King. His herbarium is the most valuable acquisition that the fern collections have had for many years, the more so as it comes from a region which was previously somewhat scantily represented. The Oxford University Exploration Club has presented the botanical collections made by $\mathrm{Mr}, \mathrm{H}$. G. Vevers on the recent expedition to Greenland. This comprises more than five hundred numbers. Dr. G. N. Humphreys of the Mount Everest (1936) Expedition has sent to the Museum a collection of 88 flowering plants which he made at the higher camps used by that Expedition. Considering the conditions under which Dr. Humphreys worked, the plants are very well collected and dried, and he appears to have obtained a good representation of the alpine flora. The Department has particularly fine collections from Nepal, and Dr. Humphreys' specimens will add further to the importance of this Himalayan material. A number of the species represented reach the altitudinal limit of flowering-plant vegetation, and it is particularly valuable to have the precise altitude at which each specimen was collocted.

\section{Colonial Territories and Economic Opportunity}

Tue Advisory Committee of the National Executive of the Labour Party has prepared a pamphlet on "The Demand for Colonial Territories and Equality of Economic Opportunity" in which the position of the three 'dissatisfied' Powers-Germany, Italy and Japan-is examined (Labour Party, Transport House, Smith Square, London, S.W.I. 4d.). In analysing access to raw materials, the division of the world, recently adopted by the Economist, into the British Empire, the French Empire, the Dutch Empire, the U.S.A., the U.S.S.R., and the rest of the world, is used. The general conelusion is reached that colonies are of some, but not of great, economic importance. Only in the case of rubber are the colonial possessions of a Great Power of dominant importance. It is held that the abolition of discrimination rather than the exchange of territories should be the objective. To this end, the Labour Party should advocate the bringing of Colonial possessions, such as those of Britain in Africa, under the mandates systemapproximately of the present $B$ Class of mandates. The pamphlet is full of information and deserves close study.

\section{Teaching Electric Cookery in Switzerland}

IN the Electrical Age of October, a magazine published by the Electrical Association for Women, an interesting summary is given of Swiss methods of teaching electrical cooking in schools. Swiss manufacturers supply special electric cookers for use in school kitchens. These are made to stand away from the wall so that access can be obtained from all sides. The oven is placed on one side instead of being put under the hot plates as in the ordinary domestic cooker. This facilitates access to it and at 